Portland State University

PDXScholar

\title{
A postulated alternative to current Oregon marital statute (ORS 106.71): a frankly revisionist analysis of the concrete situation
}

\author{
Ken Jones \\ Portland State University \\ Ray Kendall \\ Portland State University \\ Jan Nolley \\ Portland State University \\ Jill Weeden \\ Portland State University
}

Follow this and additional works at: https://pdxscholar.library.pdx.edu/open_access_etds

Part of the Family, Life Course, and Society Commons, Gender and Sexuality Commons, and the Social Work Commons

\section{Let us know how access to this document benefits you.}

\section{Recommended Citation}

Jones, Ken; Kendall, Ray; Nolley, Jan; and Weeden, Jill, "A postulated alternative to current Oregon marital statute (ORS 106.71): a frankly revisionist analysis of the concrete situation" (1971). Dissertations and Theses. Paper 1459.

https://doi.org/10.15760/etd.1458

This Thesis is brought to you for free and open access. It has been accepted for inclusion in Dissertations and Theses by an authorized administrator of PDXScholar. Please contact us if we can make this document more accessible: pdxscholar@pdx.edu. 


\section{(A POSTULATEd aLTYirnative}

IU A CURRENT OREGON MARITAL STATUTE)(ORS 106.071):

A FRANKLY REVISIONIST ANALYSIS OF THE CONCRETE SITUATION

$$
\begin{gathered}
\text { by } \\
\text { Ken Jones } \\
\text { Ray Kendall } \\
\text { Jan Nolley } \\
\text { Jill Veoden }
\end{gathered}
$$

A practicum submitted in partial fulfillment of the requirements for the degree of

MASTER OF SOCIAL WORK

- Portland State University

1971 
APPROVED:

Herbert $H$. Hansen

School of Social Work

May 17, 1971 
According to the Oregon Marriage statute an applicant for a marriage license must present a physician's statement that be is free from certain mental and physical conditions. When the examining physician is not satisfied that the applicant is free from these conditions, the applicant is referred to the Committee of Three, a special standing committee appointed by the Board of Social Protection for determining whether or not a license to marry should be granted.

In the spring of 1970 such a situation was referred to the committee for its consideration. As a result of the committee's involvement with this applicant, the question of enforcability of the current physical mental prerequisites to marriage became a concerm. The committee noted that no specific definition of the individual categories was included in the statutes that could be applied objectively the the committee in determining an applicant's fitmess to marry.

In an attempt to clarify these areas the committee and its parent group, the Board of Social Frotection, determined to investigate marriage laws of other states seeking more valid (and/or realistic) definitions of physical and mental prerequisites to marriage. After making preliminary inquiries It was realized that a more comprehensive study and evaluation were required. A study of this nature, however, required considerable time and expense, neither of which were 
avallable under the existing program structure.

It was at this point that we four students from the School of Social Work became interested in the possibility of working with the Board of Social Pratection in this endeavor.

Both to meet the research requirement of the school of Social Work and to provide pertinent information to the Board an informal contract was formulated between us and Dr. Edward Press, State Health Officer, who serves as Secretary of the Board of Social Protection. He were requested to research and propose an enforceable marrlage law to the Board which might be presented to the oregon state Iegislature for consideration. 
DISCUSSION

Much of what was presented was relatively objective data. We feel that a necessary bridge to our final recommendation is a statement of our value positions - which necessarily filtered the data. We w1ll explicate these values by briefly discussing what we see to be central issues.

What is the function of law in United States society today? Law is certainly regulatory - but more important is the basis for regulation. As we have seen our legal heritage gives both the individual and society rights and responsibilities. The problem has been in defining the balance among these four elements. Obviously we have a long-time legal tradition of individual rights. These rights were limited with the coming of social legislation and court decisions stressing societal rights to protect the general welfare; the individual's responsibility was then stressed along with his rights. It seems to us that the fourth element - societal responsibility - has not been as clearly defined.

It would seem to us that a consclous effort must be made toward balancing all four of these elements. Not only does the individual assume a responsibility as a spouse, but perhaps society has a responsibillty to prepare him to 1111 this role. Not only does the individual have a respon- 
sibility as a parent, but perhaps soclety has the responsibility to help him fulfill that role. We are not saying that society does not have the right to intervene but this has to be within the context of individual rights.

Using this as a value base, two broad relationships seom important to us in considering legal change: law and research data, and law and societal values.

In looking at the research data, we were consciously using the basis on which the Loving decision struck down a marriage law as unconst1tutional: "Insupportable basis". The decision specifically states:

To deny this fundamental freedom on so insupportable a basis as racial classification...so directly subversive to the principle of equality at the heart of the Fourteen th Amendment, is surely to deprive all the State's citizens of liberty without due process of law.

This seemed to suggest two things. First, the courts are defining and delimiting the power of the state to protect the general welfare at the expense of individual rights. There is support for this in other areas as well, as in the decisions protecting the rights of both juveniles and adults accused of criminal offenses. Secondly, in an age in which much has been objectifled, the courts are looking not only at social values but at scientific data; simplistic cause-and-effect explanations of arbitrary categories of poople have been rejected and the court seems to be saying that no other "support" seems evident to them. In commenting 
on the Loving decision, one author points out that it "provides a rationale for questioning state marriage statutes that may not be justified on sound social or moral principles and are supported only by custom and prejudice." (Foster, 1968)

After a review of the research literature we find real problems in two areas: definition and prediction.

The categories specified in the Oregon statute are not defined in the statute (as we noted in our preliminary paper), they are impossible to define clearly at our present level of knowledge. It seems paradoxical to deny the right to marry to certain specified populations, in the light of contemporary scientific knowledge, and not define the specific labels nor make any attempt to determine whether, in fact, the individual can function as a spouse or as a parent. Interestingly, the kinds of predictions regarding progeny that we can make are not the categories included in the law (1.e., hemoph1lia), and the categories whlch are included are not widely accepted as passing their "objectionable" traits genetically to their children. Frobably most distas teful to us is that such arbitrary categories seem discriminatory In Intent and certainly "Insupportable". Without support It is concelvable that any number of categories could be added. Having parented 1llegitimate children, recelving welfare, being eplleptic, or having other chronic physical 
dis wase might be evaluated also.

Although the data we have seems insufficient to validate the continued use of such mental and physical prerequis1tes, 1t is sufficient to indicate to us that if a decision must be made 1t should not be a medical-only decision.

Socletal values seem to us to be even a more important area of consideration. The statute in question obviously mirrors past ralues. It is our position that legislation must be kept reasonably current in an age of rapid social change.

What are current values? What, for instance, is marriage today? What is famlly? Soclologis ts have long differentiated the two but for practical purposes they have tended to merge in western culture. While the oregon statute on mental and physical prerequisites could be an attempt to protect the rights of the contracting parties, the Attorney General's opinion implies protection for dependent children. (Preliminary Paper) So this statute also equates marriage and family.

Within the culture the two concepts are now diverging In some ways. With increasingly reliable birth control some marriages are not resulting in children; on the other hand extra-marital unions, many with children, are increasingly common. With the divorce rate rising it is impossible to predict who will be providing the parenting for children 
of any union. Narriage and parenting are simply not synonomous. Consequently we do not feel that marriage and famly can now be sufficiently rellably equated as the basis for law.

Why is marriage the point of intervention? As one man observed in regard to the V.D. testing prerequisite: "You might just as well test any group, say, all blcycle riders." For a complex of reasons society has invested in marriage as a major point where responsibllity for the general welfare is centered. It is obvious to us that 1t is not fulfilling this responsibility. It is our feeling that social responsibility must be broader if it is to be effective - and the points of intervention changed to include such things as better preparation for adult roles and special services to chlldren. Only then do we see social rights and responsibilities as complementary to individual rights and responsibilities -- and not excercised at the expense of the Ind1vidual. 


\section{PROCESS}

After formulating the contract. w1 th Dr. Press we pegan a revlew of legal literature, philosophy and history for perspective. We talked with attornies, a psychiatrist and two legislative dandidates.

Wo developed a rough statement of positions which fell rather naturally on a continuum from a very liberal to a very restrictive position and discussed them with Herbert Hansen who has acted as our faculty advisor and 1s also a member of the Board of Social Frotection and of the committe of Three.

We concurrently began a large scale review of soclal and psychological ilterature regarding the specific categorles, the institutions of marriage and family, and of genetics. We explored emerging and changing cultural values about parenting with people from Zero Population Growth and Planned Paren thood.

By late october we had refined the positions and the research material in to a "Preliminary Paper" which was presented to the Board of Soclal Protection with a request for specific direction in terms of the original informal contract. No decision was reached.

We shared our information and materlal with the oregon Medical Assoclation Legislative Committee as Dr. Press was hopeful of coordinated efforts with them and their concern 
about the marrlage statute. They have subsequently developed and defined their own proposal which reflects a different value base than ours.

We met a second time in December 1970 with the Board of Social Protection. Again no further clarification of the wishes of the Board. A further meeting was held in January and again no clear decision was reached by the Board. Although we have done further research which could be used in proposing legislation the Board's indecision has resulted In a mutual agreement that the contract has been fulfilled. From the time of the original commission to the present our research has moved through three roughly discernable phases: (1) beginning with primarily legal data to (2) consideration of relevant social and psychological literature to (3) consideration of specific individual values culminating in behavior which often 11 mits and restricts the objectivity of the type of data noted in the first two phases.

The data has increasingly reinforced us in tne direction of the present recommendation. by october we had sufficient Information and documentation to formulate the Preliminary Paper which remains the heart of our research. Further documentation in some of the areas since has increasingly reinforced our conviction of the validity of a refinement of Position One. 


\section{RECOMMENDATION}

It is our recommendation that the mental and physical prerequisites spec1fied in the Oregon Marriage Law be removed. Of the varlous positions and their variations discussed in the Preliminary Paper we recommend registration rather than licensing and the provision of pertinent related medical and social information and resources. We specifically adrocate provision of adequate and expanded voluntary pre- as well as post-marital counseling. We urge development of broad and pervasive specific education as well as phllosophical base for marriage both in the formalized school system and in the broader community. We are cognizant that the cost to soclety is a significant factor. However, the possiblilty of infinite savings in terms of problem marriages and parenting and more successful and satisfying modes of living may well justify the expenditure. 
APPENDIX A

Prellminary Paper 


\title{
PRELIMINARY PAPER
}

\author{
Ken Jones \\ Ray Kendall \\ Jan Nolley \\ J1Il veeden
}

October 19, 1970 
..we are only the techniclans who translate the ldeas of other people into legalease. But before we can try iranslating, we have to have somethins to translate furnished oy people other than lawyers, ..either the people at large or the specialists in those fields who are supposed to have some.. krowledre as to - what is good or bad in the family field..We cannot say whether sterilization.. or divorce is good or bad, we can only give it the proper form.

Professor Max Rheinstein Untversity of Chicago, School of Law spoken at the Institute of Fam1ly Law, 1959 
In the request to develop a proposal for a revision for the Marrlage Law in the State of oregon we have only had the guldeline of "enforceability". This allows a rather broad spectrum of possibilities. ie have, therefore, developed the following continumm of positions and ask that we be given guldance in the direction to pursue. It is our plan that with the selection by the Board of Social Protection of one of these positions that we can refine and enlarge upon that position and provide appropriate background relevant to $1 t$ for presentation to the 1971 Legislative Session. 


\section{POSITIONS}

Position I

To marry a couple has only to register with the county Clerk or other desienated public official their statement of marriage or obtain from a designated public official a Ilcense to marry.

A. Vith a time period ("waiting period") between applyIng for a reglstration certificate or license and its final filing.

B. With provision for voluntary counseling.

C. With provision for voluniary sterlization - at public cost if necessary.

Discussion:

Elther registration or license procedure would comply with society's need to tabulate, regulate as to age, parental consent and offer figures to compare with divorce rates.

This is an entorceable requirement. The only violations of such.a law would be "common law", bigamy, age violations, use of force or fraud and relationships of consanguinity.

Ilcensing implies meeting certain standards to receive the permission of the state to narry. It has traditionally implied public notice of the initition of marriage relationship through a ceremony. A possible benefit of retaining the licensing procedure is recognition of a minimum age requirement which must be met.

Registration as a recordine of intent to marry would seem to us to satisfy the same purposes as licensing if the 
arbitrary categories are dropped. Age of consent, for example, could be the one pre-requisite to registration of marriage.

Ificensing has historically required a ceremony to sanctify or complete the marrlage process. Registration would recognize differing values within our society jet allow a ceremony if the couple desired.

Such legislation releases the medical profession from sole inftial responsibility for making judgments as to the "ability" to marry of individuals. We understand the opinion of the Attorney General (letter July 7, 1970 to Dr. Press) to mean that the ablilty to marry is tantamount to the "ability" to responsibly parent.

The rights of individuals to marry is protected and recognizad.

"All rould agree that there must be some ninimal legal regulation of marriage but that this regulation is not to be inconsistent uith the conviction that marriage is and should renain tine most intimate, personal, and legally unsupervised contract ino:m to lat... This consensus received a certain constitutional status winen a unanisous Supreme Court, writins tisrough Cinles Justice Earl farron in the ioving decision of June 12, 1967, stated: The Frovola to marry has lons been recosnized as one ô the vital personal rights essential to tire orderly pursuit of happiness by free men. The Lovin decision ruled that the government, in the exercise of whatever power it might have rith respect to the formation of a marriace, may exercise that poiver only to safecuard sone public objective whtch is domonstrably more important than the diminution of the humen freedoid to werry a person of one's cholce...

...The crucial princlule for all thinking on the matter micht be Chief Justice iarren's statement, in Iovinc, that: 'lerriage is one of tine basio civil 
rights of man, fundamental to our very existence and survival.' If one starts vith the primacy of each Individual!s ireodom to marry, not a iew of the statutory restrictions on the right to marry would be set aside...

...Although persons applying for a 'Ilcense' to marry may not feel any particular resentment at the fact that the state camnot really frant permission or a 'Iicense' to exercise a furlamental humen right, it rould nonetheless be more approprlate to have a marriage registration act raticer than a marriage license law."(Drinan, 1969)

A disadvantage would be the elimination of the identification of active venereal disease cases. iie understand, however, that relatively feil active cases are identified at the present time through tise pre-marital certification process and that the processing cost to the state of oregon is rather high. We also have been told that the oregon Medical sssociation is seeking a change in this part of the code in terms of the high cost vs. the low case identification. (See the section which aiscusses syphilis.) (I)

Another control which rould be removed by the registration/liconse only concept is that of propogation by mentally retarded, mentally.11l, etc. -- at least the lcsal propogation. Is it realistic to suggest that many persons of whatever mental or physical conditions do not and would not enfage in sexual activities sans benefit of the license and cercinony?

Perhaps most critical, this position is possibly someWhat liberal and pormissive to gain locislative support. Variations of this position are noted. Ve suggest a "walting period" provision might be a realistic and 
constitutionally admissable limitation which might be included. It would require that those marrying have at least a fev days to consider the 1mplications of the act and would, perhaps, eliminate a few "impulsive" contracts.

There seems to be a movement for the concept of premarltal counzeling to cut dow the divorce rate -- particularly among the late teens and early twentles. Marion County statistics appeared in The Statesman August 16, 1970, noting that nearly half of the 574 divorces in Narion County last year involved couples who had been married as teenagers. Judge Joseph Felton, Department of Domestic Relations, believes, according to this article, that more pre-narital counseling for young people would help out the divorce rate and advocates that the legislature provide measures requiring teen-agers to present a certificate from a qualified counselor prior to the time their marriage license is issued. We find, hovever, that when and there ver pre-marital counseling is reouired that costs have been bigh and results negligible. (2)

ile suggest that provision be made for voluntary pre-marltal counselino -- avallable to all, not just to teen-agers. (j) The multi-responsibilities of marriage and child rearing, the vast personal and interpersonal adjustments of early marriage are as sioniflcant and dificult to older people as to teen-acers. Imposed and required counseling reaps resistance to acceptance of the counselor's goals. We suggest a pilot study project in one or two 
counties during the next biennium providing voluntary counseling service to any contemplating marriage to determine the need, acceptance and effectiveness of such specific services.

He also suggest provision for voluntary sterilization -at public expense if necessary:

In terms of the current recognition of the population explosion and tine need for a control of tine birth rate -- but vilin recognition of individual rights.

As of August 1, 1970, physicians in Oregon vere notified by itate Public ielfare that the asency vould allow payment for medical procedures for sterllization, male or ferale, and for abortions within state statutes.

There are, hotever, many oragonians who are not on iielfare but cannot afford the costs of the above medical procedures. is suesest that they be made available to all. Such a provision logically parallels leglizing abortion as a societal recognition of the changing needs and values of society.

Position II

We suggest the registration/license concept of Position I plus continuing to require the blood test for ldentification of active venereal disease. Discussion:

The discussion following Position I, except for that about venereal disease requirement being vaived, applis, as rell as the following.

Requiring the blood test would maintain a direct attempt to control the venereal disease rate. Fie have, however, already combented on the high cost versus the low case identiflcation ratio of the present system and 
recommended use of the funds for expanding other educational and social tools in an attempt to control venereal disease -especially in terms of the current soxring rate of veneral disease and the changing population effected.

Position III

As with the first two positions, registration/Ilcense concept with a designated public official with the possible variations of voluntary counseling, voluntary sterilization, and/or time or waiting period, but requiring a medical clearance $w 1$ th present limits as to mentally retaràed, mentally 111 and active venercal disease. ire would provide a specific definition of mental reterdation and mental 1IIness. (See Appendix A.)

Discussion:

The present lav does NOT define these categories. Enforcement is highly dependent on the individual interpretation oy the doctor involved. This would be an attempt to provide"specific ouldelines.

He question, nonctheless, if there would in fact be more uniform enforcsment and interpretation than of the present la\%. iile have concem as to whether the family physician who has a personal imoviledge of an individual might use this knowledge as a base for a more personal judgment tnan the doctor who does not beov the person? Would this be more enforcoable than the present statute? Position IV

Rotain the present law. 
Discussion:

This law does ldentify and allow some societal control of some problem populations -- or at least allows society a feeling of well-belng in that it feels it is taking great steps in the breeding of a better race. (Cook, 1950.)

It is not, accordine to the original request for this study, enforceable: It is not uniformly interpreted or practiced medically.

Position $V$

Provision of stricter warriage requirements. For example, compulsory pre-marital counseling or perhaps meeting with a screening board representing the medical, legal and social disciplines to evaluate the ability and readiness of the couple to assume marital and famlinal responsibility. Discussion:

The counseling approach would allow opportunity to dispense approprlate social, leģal, economic (budfeting) information so couples can be at least more knowledgable prior to marriage.

But would this be an enforceable provision? Hill as many or even nore couples marry out of state to avoid the requircment? Who would select the counselors, the content of the counseling experience and pay the counselor?

Hould suci a requircment in fact be product1ve? There is no real evidence that imposed counseling, as earlier noted, reaps success. 
The multi-discipline screening board would, at least, broaden the decision making from a medical only base. Society has a stake in problem areas of marriage and family relationsinips far broader than these narrow physical ones. But again the question of enforceability must be raised as well as: tho would serve on such a board? that bases of judgments could be provided to insure uniformity of enforcement? Who would firance the cost of such an approach? Is such a restriction truly harmonious with the right to marry earlier cited in the Ioving decision? (Drinan, 1969.) 
1. Georgia, District of Columbia, Minnesota, Maryland, South Carolina and the Virein Islands do not have the venereal disease test requirement. ife are corresponding with them for statistics and comment.

2. Adams reports an Iowa exporiment of a $2 \frac{1}{2}$ year progran of conpulsory promarital counselinf for teenagers which produced negative results. Fever than one half of the paronts or teenagers felt they had recelved any help. Nore significantly The ramily Service dency felt that many couples had reacted very nesatively and the agency had become merely a police force.

3. In an attempt to offer oremarital counseling an interarency effort is being made in Grand Junction, Colorado. This program is scheduled to go into operation later this month. It ls anticipeted

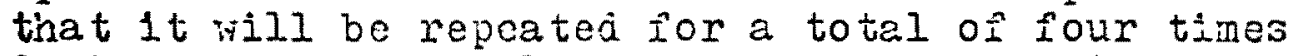
during the coming calcndar year, each session to correspond with the peak seasons in marrlages. E.:-

The prosram is to cover a total of five sessions, distributca over a period of ilive veeks. Sach sessicin is to be devotect to a zpecific area oI marriage, such as inances, sexual and interpersonal adjustuent, and othcrs. Fach meetine vill be divided into two sections, dealing with a speaker on the topic and followed by group sessions led by professional people. 
The concept of the family as the basic unit of society has been a part of every culture. And every culture has developed rules - both formal and informal - which have Ilmited the freedom of the individual and thus protected the welfare of the larger group. Narriage laws have been such rules, ways of assuring mutial obligations of the marital partners in regard to such matters as child-rearing and property rights.

The American family is governed by rules within the English tradition and American family law cannot be seen apart from this tradition. English law - common law, statutory law and judicial decision - can be seen to form the basis of wany of the stipulations of our present marriage law and a brief history is necessary to see the law in perspective.

Common law was the total system of English justice through the Fourteenth century. Theoretically it is the customs and traditions of the people as defined (not created) by the courts. (Found, 1921) over the centuries common law became ossified - old customs became inflexible legal rules of conduct - and common lan decisions were then supplemented by "equity jurisdiction" or the defining of conduct in terms of "good consclence." (Clark, 1957) Judiclal decision then came to include both of these traditions. The development of a parliamentary body added the dimension of statutory law. All three areas continue to overlap and change in one area 
demands adjustment in the whole legal system.

The American colonies were bound by English law and following the American Revolution, the various states adopted constitutions, and common law not in derogation of these constitutions, as the basis of their government. Oregon marriage law shows many of the inconsistancies inherent in this heritage. For instance, the concepts of vold marriage a null marrlage - and voldable marriage - a marriage which can be repudiated by a marital partner and which is for practical purposes neither null nor valid - is a product of an early dispute and compromise between ecclesiastic and secular courts in England and has been seen by some to be unworkable and certainly confusing today. (Drinnan, 1969) States differ in what they today define as vold and voidable and many of the categories, such as non-age, mental capacity and physical capacity, come from the customs of early England and have limitations in their application to contemporary situations. I one of the categories of a vold marriage in Oregon is degree of relationship (consanguinity), an outgrowth of the Church's ideas of improper marriage in the inbred Medieval community; such a legal stipulation does not allow flexibility in an age when a more realistic genetic decision could be made on an individual level.

Another instance of an inconsistancy is the current concept of licensing marriage. This was England's answer to "secret marriages" (Jardwicke Act, 1753). Frivately said vows had raised significant questions about illegitimacy and 
property rights. Centraldzed Jovernment had been too weak to make registration effective and licensing with a public ceremony was considered the necessary alternative.

While much that is seemingly unnecessary has been perpetuated, law has also continued to evolve in many areas which have paralleled social trends. In America, early family law emphasized alienation of affection, breach of promise, etc. This gave way by mid-Nineteenth Century to increased emphasis on the rights of women and children, and consequently to legislation such as divorce law, as well as broader social protections. New theories of biological and social sclence stressed inheritability of insanity and criminality, and states passed laws limiting the right to marry for such groups. 2 The 1dea of marriage as an act 1mplying responsibility to soclety was stated in the 1888 liaynard-Hill decision (125 US 190, 2051888 ) in which marriage was considered one contract in which the state had the right to intercede to protect the general welfare. Interestingly, the law we are now considerine seems to be an attempt to use categories which might otheraise make a marriage voldable in an attempt to prevent marriages of persons who will "..procreate children who could themselves become burdens upon scclety." (July ?. 1970 letter of the Attorney General to Dr. Edw. Press)

Not only family law but law in general seems to have paralleled broad social trends. In his five volume work on jurlsprudence, Roscoe pound secs common law and equity law as maturing and making a "..permanent contribution [in the] 
1dea of individual legal rights." He sees beyond this a stage of "soclalization of law" in which there is ".. increasing recognition of groups.." (Pound, Vol. I, 1959) This latter seems to describe the social legislation of the late Nineteenth and Twentieth Centuries noted above.

At this point, the law appears (through judiclal decision) to be attempting to more narrowly define the boundaries of acceptable social legislation. Frobably the best example of this can be seen in two supreme court decisions which show a changing approach to legislation to protect the social welfare. In 1942, in Skinner v. Oklahoma, a compulsory sterilization law for "habitual criminals" was declared unconstitutional. However, the basis was that the statute lacked procedural due process of law (whether the procedure insured his rights, i.e., adequacy of notice and hearing) not substantive due process (whether the liberty is important in our soclety or whether the process was an imposition on the individual). (Hastie, 1956) In othet words, the defect was lack of a hearing, not whether compulsory sterilization was just or justifiable. liore recently, In Loving v. Virginia (388 us 1 1967), the supreme court found a law agailist miscegenous marriage unconstitutional on substantive grounds:

To deny this fundamental freedom on so insupportable a basis as racial classification.. so directly suoversive to the princiole of equality at the heart of the Fourteenth imercient, is surely to deprive all the state's citizens of liberty without due process of law. (italics mine)

In commenting on the Loving decision, one author points out that it "..provides a rationale for questioning state 
marriage statutes that may not ve justified on sound social or moral principles and are supported only by custom and prefudice." (Foster, 1968)

It would seem that the states have a responsibility to consider what sound social principles are. Judicial decision demands a "supportable basis" and state laws should be reconsidered. We will now turn to discussion of social science "fact" to see what can be supported.

\section{FOOTAOTES}

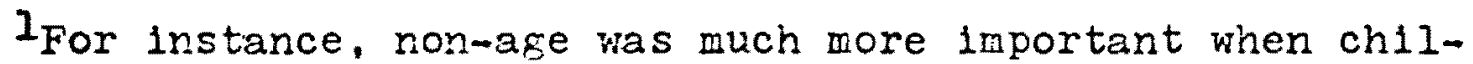
dren wore lezally chattels: mental incapacity in common law gave the rignt to invalidato marriage to tine privilesed party, 1.e., the insane party (Harper, 1962) and has nothing to do with limitine the rignt of zarriage to those who can provide responsible carenting: physical capacity to sexlally consummate marrlage implies the Catholic Church's idea of marriage as primarily for procreation and does not take contemporary population explosion problews into account.

2 Drinnan found in 1968 that 35 states still have laws limiting the right to marry to classes which imply inheritable tendencies. 


\section{SYPHILIS}

A revlew of the literature concerning syphilis, as a social problem, reveals that much of the current knowledge and practice in this area is based on weak and of ten unsubstantiated basis. Casual and often unprovable assumptions are given as premises rather than sound scientific knowledge.

Although it is acknowledged that continuing high rates of syphilis infections are occurring, there is little evidence to substantiate premarital requirements as an effective means of detection and control. There is however, evidence to indicate the contrary. The changing population of those infected, namely teen-agers, prostitutes, and homosexuals, along with the low rates of "discovery" from state required premarital testing indicates the unrealistic and inappropiate nature of such an approach.

Syphilis, once thought to be a defeated communicable disease (mid 1950's), has made a devistating comeback that again places it near the top of communicable diseases of grave concern.

The new rise has been attributed to significant higher proportions of cases effecting three catacories of people: teen-agers, prostitutes, and homosexuals.

Changes in soclal enviornment, such as industrialization. Increase and/or new patterns in homosexuality and 
prostitution are partly responsible for the rise of infection in these categories. The increasing mobility of young people, breaking of old family. patterns and old ways, has resulted in a subsequent breaking of traditional sexual taboos.

"Old cultural patterns have given way to mass conform1ty. Scientific, relibious, and social concepts have changed with often bewildering rapidity. Adolescents are frequently left with no clearly defined ethical values- no rules of behavior. In a mobile society. their relationships are of ten of a transient nature from which amoral attitudes and castal sexual encounters can easily gron." (icCary, 1967).

Studies conducted by Fublic Fealth Agencies in connection with youth, show that teen-agers infected come from families lacking in wholesome interpersonal relations, and a serious lack or realistic knowledge about sexual activity and venereal 1dsease. Geliglous conflict and guilt over their sexual activities was common, and stated as partial explantion of their infections not coming to attention of treating clinics

Eradication, or control of syphilis in these catagories is difficult, due to the nature of the circumstances of each. The teen-ager fears parents gaining knowledse of their sexual behavior, and the prostitute and homosexual fear legal repercussions should their situation come to the attention of the authorities.

When examining the current marital laws of the United States is is noted that the only premarital requirement added to American law during the twentieth century is the 
test for venereal disease. Because of advances in medical science, and the changing populations effected, it has been questioned whether the enormous expenses connected with this type of requirement can be justified at the present time.

Under Oregon's compulsory premarital syphilis tes $t$, 15.728 individuals were tested in private labs, and 19.975 were tested through the state facilities in 1969. Out of these tests 100 vere found to be reactive and 96 weakly reactive. Number of syphilis cases brought to treatment through follow-up of the premarital tests were a total of

? 5. The total cost to the state, at $70 z^{\prime}$ per test, was $\$ 13.982 .50$.

In a special report to the House of $\bar{k}$ presentives In the state of Georgia in 1965. 1t was recommended by the committee to study the liarriage Laws of the state, to repeal the requirement of a premarital blood test for syphilis. This was based on the fact that only one percent to the tests resulted in the discovery of infectrous syphilis. This recommendation was made in opposition to statements made by; The Hinisterial Assio., State Board of Health, Medical Assio. of Georgia, Federation of Women's Clubs, Georgla Congress of Farents and leachers, and the Georgla Dept. of Public Health. In their statements, the state Board of Health stated, "that even though the premarital blood test is relatively ineffective in uncovering cases of contarious syphilis, the State Board of Public Health 
would like it to remain as a prerequisite to the issuance of a marriage liscense, for it serves as a very effective educational tool."

It is evident that syphilis is a grave social problem that is much in need of our attention and energies. It appears logical however, that our efforts and funds should be directed towards more effective means of detection and control that the tradition of premarital examination. 


\section{MENTAL RETARDATION}

(Feeblcmindedness)

It is assumed by many that because the mentally retarded do not learn as easily as the rest of us, they do not share in feelings of love, our needs for recognition and dignity or our desires for intimacy and meaningfulness. Historicalfy mental retardation has been viewed for the most part as a static unchanging incurable condition. Although there were some brililent thinkers and Elfted practitioners who envisLoned the potentials of treatment for the retarded, the idea "once retarded alvays retarded" led over the years to the general practice of providing humane treatment with little hope that the afflicted individuals could ever participate In the competitive world of chvic responsibility. (Dunn, 1965.) It was a widely held belief that mental retardation was inherited, that mental growth stopped in adolescence and that since intellience was a general problem-solving behavior, then if one was'retarded at all, one was retaraed in each specific area of human functioning.

Segregation was widely used in the early part of this century for the sole purpose of preventing reproduction. Young vomen were sent to institutions established especially for females of child-bearing are. When their reproductive ycars vere past they were released to the community. (Dunn, 1965.)

Since that timo we have, of course, becone arare that mental retardation is not a single entity but rather a com- 
plex problem resulting from many causes and having many ramifications. There are at least three areas in whibh the problem must be considered: individual factors, social factors, and cultural factors. The past twenty years have seen our awakening to the realization of our obligations. He kno: today that the vast majorlty of the retarded can be successfully integrated into the mainstream of our nation's life. Govermments have interested themselves, recognizing that mentally retarded are entitled, according to their capabilities and needs, to the same privileges, opportunities and protection as other cltizens.

It is now quite clearly spelled out that society's responsibility is to provide the mentally retarded with: (1) the opportunity for self-fulfillment; (2) the preservation of personal dienity and protection of rights; (3) the opportunity to participate and to contribute; and (4) the opportunity to attain happiness. There is elso increasing recognition that he is capsile of maintaining a a reasonably happy marriage. (Hilliarả, 1956.) However, before recomenāing marriage it should be notcd that warriage for the "weakminded" is prohibited in Iova, Pennsylvania, and South Dakota, and is probably iliegal in fifteen other states: Delaware, Indiana, Kansas, Naine, Minnesota, Missouri, Montana, New Hampshire, New Jersey, North Carolina, Horth Dakota, Vermont, Virginia, Vashington and visconsin. (Strublng, 1960.) The uncertainty is due to the interpretation which may be given to the different wording of the statutes. 
In each state.

Definitions and trends:

The many definitions of mental deficiency (retardation)

(1) reflect different concerns of their authors with

respect to causes and/or manifestations, organic impairment, arrested development, social inadequacy, level of intellIgence, and even cultural factors. Winlle there has been

a continuous tradition of blolocical definitions of mental deficiency, other desinitions have existed as well. Iegal definitions have been prominent in England and in the United States. Vany states have legal definltions of mental deflciency (often established in relation to sterilization acts). As the concept of mental deficiency became broader, the social problems connected with the condition became recognized and the general attitude torard the condition chanicd. Some of the definitions adopted by state, legislatures are in terms of I.Q. Sarason in his writings on mental deficiency has taken strong exception to the tendency to construe the reterdedindividual from the standpoint of the I.Q. score. He recomends that wille intelligence tests may be adequate, even excellent, predictors of scholastic achievement, they are poor indicators of non-test or nonIntellectual activity. (Sarason, 1959.) on the other hand, Hac Andrev and Idgerton found that the scores of a sample group of retindates were hichly stable indicators of judged capacity for competcnt conduct. (Nacindrew, et al, 1964.) 
Mental retardation can be defined as slgnificantly sub-average intellectual functioning, manifested during the developwent period and associated with distinct impairment in adaptive behavior of the soclal performance in dayto-day living normally expected from a person of a particular age by the community of winich he is part. Thus, if a person who scores in the I.Q. range generally accepted as retarded, but who functions well in his particular community environment, is not considered retarded. This makes it impossible to determine definitely who are the mentally reterded. (Heller, 1968.) 


\section{FOOTNOTE}

(1) Terminology:

The terms "mentally deficient" and "mentally retarded" have been used synonomously as well as in relationship to dochotomic erouping. The professional organization $A$ both in title and organization of its journal has used the term deficicncy and the official Venual defines deficiency as a synonys for retardation. The organization of a symposiun of the issociation for Research in riervous and vental Diseases and hany otiers have used the term interchangeably. Sarasen arrued for separate definitions:

- mental deficiency voula apply to cases where organic factors vere found to be the cause of the condition; mental retardation vould be used for cases winere organic siens are not prescnt but. where there is reason to believe that social factors are operating. If the attenpt to distinguish between major types of derlciency should be abanajod there woula be no need to difierentiate betieen the two as to definition. There are indicators that retardation is preferred over deficioncy because oi less hans implications. Retarasion could ce rejected beceuse it sugeests a delay in developent rather than a deficiency in attainment. (ciausen, 1967.) 


\section{MENTAL IIIMESS}

Mental iliness is as old as the history of man. Prehistoric man sometines treated disturbances of the mand by drilling holes in the skull to let the evil spirits escape. The people of ancient Greece believed that nental illness vas caused by breating diseased alr. During the riddle Ages people still believed that mentally 111 persons vere possessed by devils. As late as the 1600's the mentally ill vere still tortured or put to death as witches or chained in dungeons. By the early 1800's physicians began to recognize mental 1IIness as a form of illness, and it became the subject of medical research and treatment. Iuring the late $1800^{\prime} \mathrm{s}$ Sigaund Freud developed his concepts of hot unconscious forces can disrupt mental health. Farly in the 1900's Clifford $i$. Beers, once a mental patient, helped establisi the commitee which became the National Association for Nental flealth. Forld iar II brought additional enphasis on the trektnent of mental 1llness. The $1950^{\prime} \mathrm{s}$ brought Intensivo researcin in to the relationship of body chemistry and mental disorders. The alscovery of the benefits of tranquilizing drues aided poychlatrists in treating many. so-called "hopeless" patients and opened new channels for researcin and investigation. One result of this research is that the notion that a mentally ill person is an exception 
is gone forever. It is now accepted that most people have some degree of mental 1IIness at some time and many of them have a degree of mental 1liness most of the time. (Nenninger, 1967.) This really should not seem surprising for most of us have a physical 1liness some of the time and some of us most of the time.

To intelligently discuss mental illness a variety of facts is needed. What is the extent of the problen? How many are affected? What are the characteristics of the mentally 111 as a group and as compared to the rest of the population with respect to such factors as age, sex, race, and occupation? Hov does mental illness develog in the indivIdual and what factors explain its distribution in the population? What are the psychological, physiological, and socioeconornic factors that may be related to caase and course of the 1liness? There exists a wide gap between the facts that we have now and those that ve need to have. To make any kind of statament that relates to the number of mentally 111 persons we need find a definition of whom we are to count -- who cise the mentally 11l? Second, we need techniques for detectine cases, and for mental disorders this is not an easy task. He are not dealing with a single entity but with a broad varlety of disorders characterized Eenerally by abnormal patterns of behavior. Some are due to known organic etiological factors; others are of psychogenic origin or without clcarly defined phycical cause. It should 
be noted that a significant number of people question the validity of the medical models of mental illness.

Although mental disorders are sometimes considered as chronic illnesses, many have acute and reversible phases. Thus in addition to defining types of abnormal behavior, we must'also specify whether we are looking for indiviouals who have exhibited such behavior at any time in their lives or only during a specifled period of time. Even if $1 t$ could be agreed upon winom to count, there still remains the problem of devising standard methods for case finding and dianosis needed for separating the population in to those who have a mental disorder and those who do not. Desplte difficulties of definition and case finding, estimates have been made of the extent of the problem of mental disorders. Fith all the shortcomings of these data, It is still apparent that they point to a single fact -mental disorders are a major cause of illness and disability in the nation. A primary stumbling block in attemptinf to deterwine tine scope of wental disorders is definition, and a primary stumbling block to define such abnormal behavior is to define adequately and acceptably what is normalcy. This is a task of almost insurmountable complexity. It is of equal importance to consider the perspective and the value system of the person or persons who is attemptins to supply the definition of "normal".

In the consideration of mental illness in relation to marriage (as vell as other social factors) is the sienificance 
of an increasing awareness that mental illness is not part1cularly linked to social class. As it is acknowledged as affecting the middle class, more positive sanctions for programing become evident. Kental iliness affecting this class is often referred to as neurotic, while a member of the lower class so aiflicted is considered psychotic. Medical definitions take precedence over the legal, and the afflicted individual is perceived as ill. Defining mental 1]Iness as medical places legal and moralistic approaches in perspective.

larriage restriction laws gre forms of negative eugonics which seeg laimed at purifying the American population of Its allegedly defective germ-plasm" and hence improving the social as well as biological quality of the American People. (Paul, 1967.) Such standards whether a marriage would result in the birth of children with inherited tendencies to mental 1liness or who would become neglected or depenaent because of mental illness, leave much to the imagination and discretion of the physician involved. These standaras should be constantly scrutinized and re-assessed in terms of the rigint of the individual to question or contradict them.

For centuries, as has been noted, it was the accepted belief that mental illness led regularly to montal disintegration and inplied an irretrievable loss. Today we knov this is absurd. The Ereat majority of mental illnesses reveal themselves as episodes and disappear, some in a matter of 
days, others often weeks or months. Some persons, even vith the nost intensive treatment, remain 111 for years or for a Ilfetime, but these constitute a very small percentage. These generalities imply that no "natural course" of mental 1Ilness exists. Being an aspect and pinase of a human $11 f e$, mental fliness fluctuates and varies with the ebo and flow of Iiving. (Fenninger, 1967)

There remains a great deal of controversy as to the relative importance of heredity and environmental factors, such as birth injuries, early experiences, emotional shocks, glandular disorders or general infections in the causation of mental disoràers. If one accepts the gene theory, then one must accept that it still remains an impossibility to predict genetically. However, the gene theory: has never been proved. Jetting aside the test of mental capacity to contract a valid narriage would be a recognition that the laying dom of a general test is futile and that every individual has to be scrutinized and assayed. (Dittman, 1957.) 


\section{DRUG USAGE}

A revics of the literature concerning drugs and drug abuse shows that this topic has becone a controversial one resulting in little progress being meje in effectively dealing with them.

The main reason for failure to come to grips with this problem is lack of lnovledae about its causes, effects and aspects of rehabilitation. It is not clear as to what constitutes a drug, nor what constitutes a drug addict. The scope of the problem and the population affected appears based on estinates, rather tian scientific data (1) (2) (3) (4).

The scope of the problem is difficult to determine. There arc indicatjons, horcver, of the cagnitude of the problem. It is estivated that the retail valuo of marijuana entering the U. S. from Hezico is in excess of fioo million annually. Officlals in iasinington estimate that nearly one hals $\hat{f}$ of all ampjetamines produced in legal laboratories reach the back market. The percentage is believed to be somerhat swaller for tine barbituatcs.

Statistics on the ablise of ampinetamines and barbituates are dificult to Eather because their videst use seems to be in a sejment of society that does not othervise break the lay or associate with criminal elements.

When attention is given to Youth in regard to the drus problem since this is vinere the greatest increases are being detected. But then again, 1 t wust be pointed out that 
young people comprise the group where arug abuse is most Iikely to be recownized because of Youth activities. It is however, strongly indicated that drug abuse is also showing significant increase among adults although this is more difficult to substantiate.

In attempting to gain insisht, some authorities have blamed the "Eeneration gap" for the current use of drugs among young people. They state that the shift from rural America inere youth played a veryimportant part, to Urban America vinere youth's role has becone confused is the basic problem. However, this again is speculation.

othes speculate that youth will respond favorably if given meaningful responsibllities that lead to some identifiable sense of purpose.

Dr. Robert Feterson, a psychologist with the National Institute of iental health, sajs: one of the real problems, of course, is that druf abuse is an "emotionally-laden" issue, which makes it difficult for parents and young people to deal vith. (Blue Cross, 1969.)

In the same vein $i t$ is felt that parents because of 1gnorance are scared. They do not understand drugs as they have no similar crperience in their own background. It is this lack of information sihich results in parents and public reaction to drug usage on an emotional level. It is felt that we will not be able to vies the area of concerm in reality teras. 
To overcome the emotional reactions some authorities state that knoviledge and education is needed that must focus not only on medical aspects but on sociological and psycholorical aspects as well, especially as they relate to motivation for using drugs.

Drug use breeds on certain forms of human misery. The major problen posed by addiction is not at all the problem of getting people to stay avay from drugs. It is the problem of getting at the sources of such misery. Until we gegin to effectively cope with them we will not have begun to touch on the real problem of adaiction with respect to marriage or any other social factor. 
(I) In Goodman and Gilman's textbook of Pharmacoloby (Gooduan et al, 1941), the tern "druss" is defined as "any chenical agent which affects live protoolasm". They comment that fer substances hould escape inclusion by this definition, but they make no attempt at iurtier definition. It would seen then that terms such as "drug user" and "drug addict" are popular misuses of the term.

The term "drug" is a voided for a great variety of products pruciased openly in drus stores (vitamins, analgesics, some non-prescription anti-jiotios, eto.) In short, what tine physician terss a drug, the layman calls a medicine or a remedy.

A clear exception is the term "wonder-orug" (penicillin, alieomycin, etc.). It seems that "drus" is acceptable and conzion where the use of the substance is novel or "wonderiul".

It may also be noted that tine term "drus user" is generally perjorative. Hinen an elderly person vitis chronic pain uses arugs, he is not regerded as a drus user, nor are those tho use alconol, cofice, tea, tovacco, insulin, vitamin preparations, or tiose who use "wonoer arugs".

The term "drus user" is applied only to those who use substances in a way regarded negatively and critically. The use of so undisciplined a - word warrants caution.

(2) Drus Addiction is a state of periodic or chronic intorication nroduced by repceted consumption of a drue (natural or sjntictic). Its characteristics include: (I) an overpowering desire or need to contirue teing the drue and to obtein 1t by any weans; (2) a tendency to increase tine dose; (3) a psycinic and often piysical dependence on the effects of the drug; (if) detrimental effect on the Inaiviaual and on socicty.

(3) Addiction: A bio-physical need or dependence for the use of a druf or chemical substance to satisfy adequate cellular function. Iack of these substances creates painful physical symptons.

(4) Chein, et al, distinguish between users and addicts 
and state that a person with a history of drug use and psychological dependence on the drug might concelvably not be an addict. The factors responsiole for arus lise might be different from the factors responsible for addiction. They describe three dimensions of addiction:

1. Presence versus absence of some signjficant degree of physiological dependence

2. Fresence versus absence of some significant degree of total personal involvement with naxcotios

3. Prescnce versus absence of some signifi(Chein, 196́.) 


\section{ALCOHOLISN}

Chronic alcoholism has become one of the great public health problems of the world. It is currently rated among the top four of the united states.

Attempts to deal with this problem in the united states has not been productive. It has been stated that perhaps the most important problems is the fallure to develop rational public policies on the use, sale, and distribution of alcoholic beverages. Blamed for this is clashes between various interest groups where conflicts between "wet" and "dry" ldealogles have been so energy-consuming trat a detached examination of American drinkine patterns and systems of control and intervention has not been possible. Conclusions about alcohol and drinling frequently seem to stem directly from the 19 th century philosophy of the American F'emperance Hovement, which held that all drinking led to drunkeness, and that by reducing the availability of the beverages, was the key to control.

The lack of agreement about what amount of drinking is acceptable has contributed to the wide spread reglect of problem drinking. There has also been confusion regarding the nature of alcoholism, and who should assume the responsibility to deal with 1 t.

Historically, alcoholism was believed to be a result of moral or personal weakness. Early attempts to eradicate 
this "foulness" from society was punishment. It was believed that if the punishment was severe enough the person afflicted would be forced to "mend his ways." It was the failure or this method that lead to the philosophy of making nIcoholic beverazes unatainable. The result of the latter was the 18 th amendment to the Constitution of the united States.

Emerifing from the experiences of the Prohibition period were new patterns of alcoholic consumption. During the Prohibition, it became fashionable for both men and women to drink in public. It also becaine quite fashionable to s: attend speak-easies, and later bars selling alcoholic beverages.

However, new concepts about alcoholism did not evolve along with the new acceptance of drinking. It was still felt that responsible and respectable people did not become alcoholics.

The "new approach" to alcoholism, viewing it as an 11 nness, began to emerge during the 1940's. Community groups composed of alcoholics concerned with their problems began to emerge. These groups later unifled into what is known today as Alcoholics Anonomous. Articles by medical and science writers dealing with the new concept began to appear. During the 1940's and 1950's, various organizations appeared based on this premise. By 1959 this concept had been accepted by many Americans. However, many people questioned this 
premise, regarding it as an excuse for lack of personal control on the part of the alcoholic. Though a lessening of the stigma attached to alcoholism became more noticeable, the controversy continues.

The shift in emphasis from that of personality weakness to the concept of 1llness became noticable in 1955 when an attempt was made to legislate relief for alcoholics (H.R. 7225) which proposed that alcoholism be recognized among the totally and permanently disabling diseases meriting disability allowances. The criticism that kept this b1ll from passage implied that it was too fatalistic. It was pointed out that under the right circumstances, the alcoholic was amenable to change that lead to a more meaningful life.

The current evolving philosophy reflects this dual philosophy of alcoholism. It is viewed as an illness, yet it is felt that with the proper resources available, along with a fore comprehensive view of alcoholism, the alcoholic is treatable.

The major handicap in overcoming alcoholism at the current time appears to be the great lag of much-needed information concerning 1t. Fast attempts to clarify the problem have been criticlzed for not viewing the problem In a comprehensive manner. It is felt that only when we are able to understand the phenomenon in all areas, and how the factors interact to cause the current problen, will we make significant gains. in attempting to deal with this. 
The need for such information was recognized on a

national level in 1966 when President Lyndon B. Johnson said,

in his message to Congress on health and education:

The alcoholic suffers from a disease which will yleld eventually to scientific rescarch and adequate treatment. Even with the present limited state of our lnowledge, much can be done to reduce the untold suffering and uncounted waste caused by this affiction.

I have instructed the Secretary of Fealth, Education and Velfare to appoint an Advisory Committee on Alcoholism; establish in the Public Fealth service a center for research on the cause, prevention. control and treatment of alcoholism; develop an education program in order to foster public uncerstanding based on scientific fact; and work with public and private agericies on the state ard local level to incluce this disease in comprehensive health prosrams. (Smithers Foundation, inderstanding Alcoholism, 1968) 


\section{STIRILIZATION}

Early demonstrations in genetics led to a highly successful activity in agriculture and animal husbandry called selective breeding. Brilliant successes in producing highly specializcd stocks were wldely recognized. There was a suggestive parallel between this experience and the existence of whole superior families. From this a handful of people in the U.S. made a completely erroneous inductive leap ana promulgated, firteen years beîre Hitler, a tineory of bulling a "Waster Race." Seventeen states passeà sterilization laws between 1919 and 1937. The segregationist character of the 1924 Imaigration Act derived directly from this same group. The theory may be thought of as "negative cuscoics" in which peopie shoving an undesireable trait are to be prevented from reproducing. This will presumably eliminate the trait. Modern Eenetics, of course, underscores the absurdity of the 1dea. Sociologically it is In the bain repugnant and in practice it is a ridiculaus delusion. This collectively compounded error became the second propulsive force in establishing the pre-marital examination. The oregon form still has a long list of maladies to which the patient is supposcd to adint if present and his statement must be notar1zed. It is then passed to the state Board of Erotection. This is the "classic" inquiry of negative eugenics, in to the occurence of feeble-mindedness, drus addiction, alcoholisn, epllepsy, etc. 
Thus, a rather general set of laws exists to provide a pre-marital examination to find cases of syphilis and lesser venercal discases, and to identify individuals suffering from an arbitrarily selected list of diseases, presumably either to prevent their marriaceor possibly even to sterilize them.

iith the greater avareness of the retardat's ability to assume a useful role in the communit has come a greater understandino of his need to live as normal and as full a Iffe as possible. Constant supervision may limit his social relationships to a frustrating degree. Constant supervision is also a burden to the parents which may lead to resentment and be reflectod in their attitude toward the child so that he may experionce greater rejection. inile sterilization will not elininate the need for supervision, it will lessen the parents' anxiety regarding possiole pregnancy and this reduced anxiety will usually improve parent-child relationships. At present there is a recognition of the normal sexual needs of the retarded individual and a realization that in some cases the retardate is capable of sustaining a reasonable, stable, and happy marriage and that marriage may be beneficial to hin.

There is little in the literature regarding the degree of success with which the mental defective can practice temporary metinods of birtin contral. Because of the growine realization that we retarded should lead a full and normal Ilfc; because of the concern that he should not 
be overburdened by children if he does not have the competency to rear them properly; and because of the greater acceptance of surgical birtis control there should be a re-evaluation on an individual voluntary basis. What factors linft the use of sterilization? The objections most often encountered are that sterilization might encourage promiscuity, that persons might be sterilized for insufficient reasons, or there might be psychological ill-effects. In view of the abuse to vich such regulation is subject (Nazl Germany as an example), the unsettled political conditions of our time, and the palicity of evidence regaraing its effectiveness, this prosram does not recommend itself for mental disease prevention, at least on an involuntary basis. However, ve feel the individual's rights are best protected if such a step is a voluntary one. 


\section{GENERAL DISCUSSION}

In considering the possibility of modifying the prejust oregon Lav regarding marriage we are in fact exploring and eveluating the significance and meaning of both Marrlage and Family in today's world. We are, additionally, discussing whether the law is a reflection of society's values todey or of the recent past -- or rather an attempt to control by the society of the socicty or of 1 ts parts.

The present code encurbers the fanily doctor with a teribly significant kind of decision about the future of the individual. Fe is asked to evaluate in what is likely a brief contact the potential of the individual to be responsible as a marriage partner and potentially as a parent. The implications of his decision are far broader than medical only: they surely are equally legal and social.

The present code defines explicitly one of the specific population segnants on wich it places linits: those with active and comunicable venereal discase. As earlier noted there is feeling and opinion that the results do not justify the cost of identifying these cases in terms of the marriage but the identification of active venereal disease is seen to be pertinent at the time of early pregnancy.

The other population secments identified as those on whom limits and restrictions as to the right to marry shall be placed are not docined, iescribed, but merely labeled. 
The concern for "Enforceability" is based on the inability for all doctors in one state to automatically know and agree on what those labels mean and to uniformly interpret and enforce them. Parsonal philosopiy, kind of training or exporicnce, pressure from (or lack of pressure from) the Individual's fanily dramatically vary in each process of decision making. Revieving the literature there is no consistent functional derinition of anj of the categories on which there is concensus within any one proiession -much less among professions. In fact, we see rather a large body of belief and tradition and little proved or provable fact. Najor decisions are thus made dally which may vell be challenged in terms of human and/or legal rights of the individual.

Additionally, we hnow of no evidence that absolutely or even strongly links the divorce rate with, for example, I.Q., Nelther is there solid evidence in the IIterature that a "mildly retarded" person will -- or is even more likely to - produce retarded children. There are studies in process to better identify causes of retaration as vell as one study to test the effects of long term programed enrichment contacts with the children of retarded parents and early results indicate that the children are not retarded. Ve see a trend to view and evaluate human functioning in a more holiatic way than, for example, categorizins a person as feebleminded because he scora at a given place on a culturally sheved acadenic-skills oriented I.Q. test. Is 
It more reasonable to scrutinize the person in terms of how he functions in several aroas, whether his family is supportive emotionally, whether he might have developed social skills wich more than compensate for his learning handicap? An institutionalized or emotionally neglected "feebleminded" Individual with no supportive family involvement wight vell be less able to nanage the responsibilities of marriage and child rearing than his counterpart with an identical I.Q. who is cherished and respected in his family and comunity. If we do not have solid evidence the "feebleminded" persons tho are likely to vent to marry will definitely produce retarded or neglected children can we morally or legally deny tha right to aarry to them?

Equally, it seems incongruous to restrict the right to marry to "mentally ill", "chronic alcoholics", and "orug adaicts" witis no definition of any of these categories and some exploration of thether, in fact, the Individuals can function as spouses and parents. Hith no solid evidence that they cannot has the state the constitutional right to deny marriaze? iould it be as valia to be concerned with the population likely to fall into one of these categories at some point in their history and be just as "right"?

If, hovever, the state has this right and responsibility to select croups of people with social, physical, emotional and intellectual disabilities and place such limits on them we suggest consideration be given of broadening the categories 
to be scrutinized and judged. There may be just as much validity to place an age maximum on the right to marry as to place a minimum as the individual may be or become senile. Neurotics are supposedly not included in the "mentally $111 "$ catezory and yet neurotlcs can be proved to be poor marriage risks and either potential psychotics or potentially damaging to the mental health of progeny. Perhaps the individual who has been found suilty of a felony or is identified as an "habitual crininal" can be vieved as a poor marriage risk as vell as a poor parental figure potentlal. There is much public concerm about the value systems of women who produce one or more illegitimate children. Perinaps individuals -female or male -- who have pruced two illefitimate children can be denied the rigint to marry. Some states have concern about the sense of personal responsibility of those who receive Public Assistance. Perhaps those who have been on Welfare, for example, for a two year period of time should be denied the right to marry. Several states have a similar concern about the eplleptic. Qualiflcaticns could be estabilshed in terms of persons uiti chronic physical discase or damage, the level of education, proof of employability and ability to support a family. Enforced use of contraceptive devices might be a consideration.

It is our position, horever, that to place ereater restrictions on the right to marry does not secm to meet the request for "enforceabilito" nor vould we suspect it would stand the scrutiny of constitutional challenge in 
view of the lovine decision. Soclety has not only a right but a responsibility to concern for the number and "quality" of its progeny but must this not be in the framework of the basic human and legal rights of the individual? Perlaps far more in the way of improving the "quality" of the coming generations can in fact be accomplished through greatly improved and increased educational tools and voluntary services in terms of these areas of concern. The lack of hard proved facts as to the very states of "mental illness" etc. as vell as to what can be inherited (and cannot) and what predictably vill happen because a child's environment included an alcoholic parent pleces back on soclety a responsibility to research the validity of videly accepted beliefs before denying any of its members the right to marry and to produce cililàren. 


\section{APPEITIX A}

The Diacnost1c and statisticel vanual of Yental Dis-

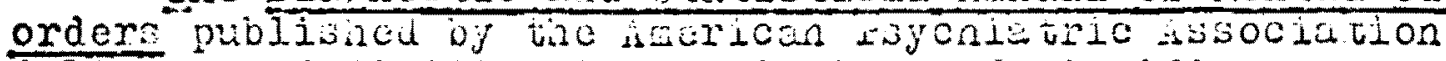
delineatos definitional descriptions of significance to this.

They state "lental reterdation refers to subnornal general intellectual functioning wich oritinates durins the developinental perlod and is associatcd with inpairment of either learning and social adjustment or maturation, or both..." They dofine the usual I.Q. Score scales and commont that this cannot be the only criterion used in mairing a diagnosis of mental retariation or in evaluating its severity. They recomend additionaliy considerins and weiching tie developmental history and present inunctionins academic and vocational, notor silils, social and enotional caturity. These necessarily are suojective judements.

Simliarly they describe mental states listing major categorica of Oreanic Brain Synaromes, Psychoses not attributed to physical conditions listed previously, Heurosis, Fersonality Disoráers and certain other nonpsychotic rental disoraers not nentioned previously, Psychophysioloric discruers, special Symptons, Transient Si tuational Dis turbances, Eenavior Disoràors ô Ohilänood and Adolescence, and condtions without manifest Psychiatric Disorcer and Non-jpecific conditiois. There apears to be in this a continuum with iev clves as to aizoreet states. At what point ao all doctors uniformly aree a person is, for any legal or moral purpose, not mentally able to be responsible for himself and his decisions? Is, in fact, the person on whose exotional state they all can agree even interested in or likely to be imrinently interested in entering a mariage contract? If and wion his emotional state chenses at what point can his legal and human rients again be restored? 


\section{BIBLIOGRAPHY}

Adams, W. J. "Marriage of Minors: Unsuccessful Attempt to Help Them," Family Law Guarterly. III(Narch, 1969), pp. 13-21.

American Behavioral Scientist: Iaw and Social Change, Stuart S. NageI, special ed, XIII(iarch-April, 1970).

Begab, H. J. "Unmet Needs of the Ventally Retarded in the Community, "Americen Journal of Mental Dericiency, (1958), pp. $712+733$.

Block, H. A. Alcoholism: Its Facets and thases. New York: The John Day C0., 1962 .

Bradway, John S., ed. Froceedirss of the Institute of Family Law. Durham, iorth Carolina: Luke university, 1959.

Breckenridase, S. P. I'he Family and the State. Chicago: i'he lniversity of Chicaso Fress, 2534 .

Chein, I., et al. The Roed to $\because$ Narcotics, Delinavercy and Social Folicy. New Iork: Easic Eooks, Inc., ly64.

Christopher D. Smithers Foundation. Lnderstandin ilcoholism. New York: Charles Scribner's Eons, 1968.

Clark, H. H., Jr. The Iaw of Demestic Relations in the U.S. (Hornbook Series). st. paul, uinnesota: vest jublising Co., 1968.

Clarke, H. I. Social Lexislation, second edition. New York: Appleton-Century-Croits, Inc., 1957.

Clausen. Jons. "ifental Deficlercy - Development of a Concept," American Journal of iental Eeficiency, IXXI (iarch, 1967), pp. $727-745$.

Collins, if. C. Defeating Alcoholisin. Fhiladelphia: Whitmore Fublishine Co., 1906 .

Cook, W. W. "Eugenics or Euthenics," in Selected Essays on Family Law. Brooklyn: ithe Foundation Fress, Inc., 1950.

Dittman, W. k. Insanity Laws. New York: Oceana Yublications, 1957.

Drinnan, R. F. "The Loving Decision and the Freedom to fiarry," oh1o State Law Journal, XXXX(spring, 1968), pp. 358-398.

"American Laws regulating the Formation of the Harriage Contract," The Anns Is of the American Academy of Political and social Science: proaress in family Law, CCCLXXXI1 (1.ay, 1909), pp. 48-57. 
Dunn, L. M, "A Historical Review of Treatment of the Retarded," in Mental. Retardat1on, J. Kothstein, ed. New York: Holt, Rinehart \& Winston, 1965.

Ehrlich, Eugen. Eundamental Principles of the Soc1ology of Law. New York: inussell \& irussell, Inc.. 1962.

Evan, Hm., ed. Law and Soc1olosy: Exploratory Essays. Glencoe, Illino1s: The Free Fress of Glencoe, 1962.

Foote, Calab, et al. Cases and vaterials on Family Law. Boston: Little, Brown \& Co., 1966.

Foster, H. H. . et al: "Family Law," Family Law Quarterly, II (December, 1968), pp. 413-435.

Frazler and Hallas. "Crime and Prostitutes Go Together," The Oregonian, (cctoter 11, 1970), pp. I ff.

Gallagher, Fichard. Disesses that Flazue riodern Han. Dobbs Ferry, liew York: Oceana Fliblications, Inc., 1969.

Goldstein, . "Population Trends in the linited States \& Fublic Institutions for the intally Deficient." American journal of Mental Deficiency. (1959), pp. 599-604.

Goodman, L. \& A. Gilman. The Fharmacolozical Easis of Therapeutics. New York: itacnilian. $194 \bar{l}$.

Handbook of the Niational Conference of Commissioners on Uniform State Lais. FaItimore: fort City ixess, inc.. i909.

Health, State Board of. "Statistics on Venereal Disease," from an interview with liary Gonzales; Uctoker 16, 1970.

Harper, Fowler $v$. Problems of the Family, revised edition. New York: The Bobbs-1:errili Co.. Inc., 1962.

Hastie, W. H. "Judicial liethod in Due Frocess Inquiry," in Government Under Law, A. E. Sutherland, ed. Cambridge: Harvard university Fress, 1956.

Heller, F. "Who are the Hertally Retarded?" Ch1ldren, (1968), pp. $43-48$

Hilliard, L. T. "Discussion on Community Care of the FeebleMinded," piedicine, (1956), pp. 837-841.

Huber, Frank, Director of Community Social Services. Interview regarding premarital counseling. Grand Junction, Colorado: August, 1970.

International Encyclopedia of the Social Sciences (1968), vol. 9. "l'he Socloloôy of' Law," pp. 50-59. 
Johnson, Lee, Attorney General. Letter to Dr. Edw. Press and the Eoard of Social Frotection regarding the intent of ORS 106.071. July 7. 1970.

Kaplan, S. S. Marriase \& Divorce. Chicago: International Institute of Municipal Clerks, 1967.

Kolwyck, C. "Ihe Ten Year Strusele for a section of Family Law," Fan1ly Law Guarterly, II(December, 1968), pp. 413-435.

Kuchler, F. W. Law of Enzaxement \& Warriage: Legal Almanac Series it 59. Dobbs ferry, New York: Uceana rublications, Inc., 1966.

Lockenour, R. The Oregon Law of Family Relations. Salem, 1941.

Lone, J. R. A Treatise on the Law of Domestic Relations, 3rd edition. indianapolis: ine bobos-nerrill Co.. Igż.

McCary, J. L. Human Sexuality. Frinceton, N. J.: D. Van Hostrand Co., 1967.

MacAndrew, C. and $R$. Edgerton. "I.Q. and the Social Competence of the Frofoundly retarded,"American Jourmal of vental Def1ciency, LXIX(November, 1964), pp. 305-390.

Madden, J. W. Fandbock of the Iaw of Eersons and Domestic Relations in the Listed states (rorndook series). st. Faul: West rublisining Co., 1931 .

Martindele-Hubbell Law Directory, Vols. I-V. Summit, N. J.: vartinciale-nidedi, inc., 1970.

Nenninger, $\mathrm{K}$. The V1tal Ealance. New York: The Viking Fress, 1967.

Morland, J. H., ed. Keezer on the Law of Marriage and Divorce. 3rd ed. Indianapolis: tive Boobs-merrill co., 1923 .

National Association of Blue Cross. Erug Abuse: The Chemlcal Cop-olit. U.S.A., April, 1969.

Faul, J. "Population Guality and Fitness for Farenthood in the Iight of State Eugenic Sterilization Experiences, 19071966." Population Studles, XXI(ivoveroer, 190́7), pp. 295-299.

Peck, E. The Itw of yersons and Domestic irelations, 3rd ed. Chicago: Calianan d. Co.. 1930.

Plaut, F. A. Alcohol Froblen. New York: Oxford University Press, 1967. 
Pound, R. The Spirit of the Common Law. Boston: Marshall Jones, 1921.

- The Develonment of Constitutional Guarantees of Liberty. Niew Haven: Yale university Fress, 1957.

- Jurisorudence, Vols. I-V.' St. Paul, Minnesota: West Publisning Co., 1959.

Purtell, T. C. Tonisht is Too Late. New York: Faul S. Erickson, Inc. 1965.

Report of the Committee to Study the Marriare Iaws in Georria, House Kesolution it22I. Ailanta: iouse of Hepresentatives, December 1, 1965.

Sarason, S. B. Psycholosical Problems in Rental Deficiency. New York: Farper, 1959 .

Shaw, C. H. and C. H. Uright. "The Varried liental Defective A Follow-up Study," Lancet, (January, 1960), pp. 273-274.

Strubing, P. H. and D. H. Scully. Marmiaze of Eorons. Human Betterinent Association for Voluntary sterilization, 1960.

Tiffany, $W$. C. tandbock on the Law of Persons \& Domestic Relations, 3rd eu. st. Faul, vinnesota: vest rubitening Co., 1921.

U. S. Department of Fealth, Education and Welfare. Syphilis, Public Health Services Fublication $\#$ 743. Washingion, D.C.: U. S. Goverrment Printins office, 2968.

Vernier, C. G. American Family Ians: A Comparative Study of the Family lay of the to Aerican Dtaces, hasta. the

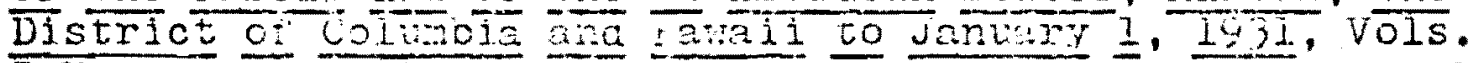
I-V. Falo Alto, Califorria: stanfora university Press, 1931.

Warren, C. "The kew 'Liberty' inder the Fourteenth Amendment." Harvard Iaw Ieview, xuXIX(1926), in Selected Essavs on Constiuntonal Law. Cambriage: Harvard LaW Heview Association, 1952 .

Whitney, E. D. The Lonely S1ckmess. Boston: Beacon Fress, 1965.

Winnet. N. S. \& W. B. Gibson. Family Law. Fhlladelphia: Committee on Continuing Legal Education of the American Law Institute, 1952. 